\title{
Rising Islamophobic Discourses in Europe and Fight Against Islamophobia on the Basis of International Organizations
}

\author{
Umut Kedikli, PhD. \\ Department of International Relations, \\ Karabük University \\ Mehmet Akça, MA \\ Social Sciences Institute, \\ Karabük University
}

Doi: $10.2478 / \mathrm{mjss}-2018-0001$

\begin{abstract}
European Civilization was built on the concepts of multiculturalism, tolerance, and dialogue but in the post-Cold War period, without considering these concepts, some European politicians, scientists, and the press have associated concepts of conflict, terror, disintegration, exclusion, and assimilation with Islam. Anti-immigrant and anti-Muslim attitudes are viewed as a new coherent ideology to replace anticommunism following the post-collapse period of the Soviet Union. Thus, a new enemy image and an exclusionist and alienating discourse aimed especially at Muslim societies in Europe were created after the 1990s. Subsequently, this new discourse diffusing across the European continent is referred to as "Islamophobia". Gradually Muslim immigrants are perceived to be the number one fundamental cause of politic, economic and social issues in European countries so Islamophobic discourses have intensified following the 90s. The aftermath of the September 11 attacks, the actions of terror organizations claiming to commit their attacks in the name of Islam in the world -and especially in Europe- have contributed to the spread of Islamophobia across Europe. Extreme-right wings in pursuit of taking advantage of all these negative circumstances for political gain attempted to find public ground by reflecting Islam as a religion of violence and Muslims as 'terrorists.' In this article, it is argued that concrete Islamophobic discourses erode some certain values such as human rights, democracy, plurality and multiculturalism, which Europe was established on these. It is also showed that actions of various extreme-right parties and other wings in different European countries accelerate this process. Policies adopted by international organizations to fight against Islamophobia will be analysed and the problems encountered in these efforts will also be presented.
\end{abstract}

Keywords: Islamophobia in Europe, Human Rights, Islamophobic Discourses, Pegida, Fight against Islamophobia

\section{Introduction}

In the last 30 years, some certain communities in Europe have associated Islam with conflict, terror, integration problems, exclusion or assimilation and so on; instead using it in the context of multiculturalism, tolerance and dialogue. Obviously such a policy is not a coincidence, as before the dissolution of the Soviet Union, the joint holding ideology of the West was the discourse of fighting against communism. When it lost its effect these communities started to look for a new one. Since the early 1990s, a new enemy image was created through an exclusionist and alienating discourse, and it was especially against Muslim communities living in Europe. This new discussion spreading 
across the Europe is described as Islamophobia. After the September 11, 2001 terrorist attacks, there was an increase in the actions of terrorist organizations claiming to act in the name of "Islam" which has also paved the way of rising Islamophobic thought in Europe. The extreme right-wing groups which want to turn this terrorist acts to political rants, have begun to take advantage of those who consider Islam as a religion of violence and Muslims as 'terrorists.' On the other hand, the rising voting rates of extremist right-wing parties both in country based and in the European Parliament elections in 2014 are a clear indication of this condition, so the European geography and their international organizations started to argue their fundamental values, like human rights, democracy and multiculturalism in the focus of anti-Islamic intolerance, xenophobia and intolerance to differences causing a dilemma within itself.

The present study investigates the influence of extreme-right parties on expansion of Islamophobia across Europe by exploiting various social, political and economic issues and replacing them with xenophobia, anti-immigrant and especially anti-Muslim concepts. The study also covers Islamophobic discourses of political parties in major European countries, in Europeancentered international and supra-national institutions and organizations -such as the Council of Europe (CE), the European Union (EU) and the Organization for Security and Co-Operation in Europe (OSCE)- and some anti-Islamic events happened in these countries. In the final part, the study analyzes how institutional determinations and policies adopted to fight against Islamophobia are threatening the peace and security on the continent and especially within the scope of the European-centered international organizations. Besides, issues encountered in the context of fighting against Islamophobia are also exhibited. The study finally assumes that during the postcold war period European right-wing extremists have changed the perception of the communist threat with xenophobia -especially against Muslims- as a new propaganda tool which caused expansion of Islamophobia across the continent and, as a result, the perception of Muslims as real causes of internal problems faced in European countries.

\section{Methodology}

Whereas general view of Islamophobia in Europe and fighting against its consequent problems are included in this paper, reports published by organizations, statistical data, election mottos of political parties and public statements of European politicians and Islamophobic attitudes of magazines and newspapers published in Europe are also analyzed. In this study examples and expressions of anti-Islamic discourses in European countries such as Austria, Germany, France and Norway are given. How the propaganda regarding Muslim immigrants is responsible for the negative impact of the economic crisis in 2008 in Europe caused an increase in the voting rates of right-wing parties in some European countries is explained through the tables. Despite the increasing attitudes of Islamophobia, decisions of European-based international organizations like CE, EU and OSCE regarding this discourse as a threat to the peace and security in Europe and their suggestions about which measures to be taken and documents published by them to struggle with the Islamophobia will also be included in this analysis.

\section{The Rise of Extreme-right Parties Using Islamophobic Discourses as Political Leverage in Europe}

Muslims are the second largest religious population in Europe. European Muslims resemble to a mosaic comprised of various ethnic backgrounds, languages, religious tendencies, cultural traditions and political views. The Muslim population in Europe is mostly composed of Muslim groups from Turkey, North Africa, Middle East, Pakistan, Bangladesh and former Yugoslavia (Aydın\&Yardım,2007:4).According to the current demographic data, the population of Muslims in the EU is about thirteen million, which constitutes $3.5 \%$ of the overall European population (European Monitoring Centre on Racism and Xenophobia -EUMC Report,2006:3).Aftermath of the Cold War era, national concerns have come to prominence across the Europe and September 11 deepened Islamophobia, racism and xenophobia causing fractures among society. In a period when politics is highly affected by the subjects concerning Muslims, foreigners and especially 
increasing number of immigrants, in Europe, the number of those who think Islam has no place in the future society of Europe is rising to a threatening level.

The extreme-right wing has been on the rise across Europe after the 80 s discussing the subject concerning economic and socio-political practices and their tendency to Islamophobia peaked up in the post-cold war period, gaining ground upon these events. An extreme-right party come to power as a coalition partner in Austria in the beginning of 2000 (Alsaayyed and Castells, 2004:1-10).In 1999, Austrian extreme-rightist Freedom Party come to power by receiving $27.3 \%$ vote rate under leadership of Jörg Haider which triggered the rise of extreme-right votes almost across Europe creating a domino effect. Vlaams Belang in Belgium, Pim Fortuyn's List in Holland, Progress Party (Fremskridts patiet) in Norway, Public Party in Switzerland, Sweden Democrats (Sverige demokraterna), Northern League (Lega Nord) in Italy were the examples of extreme-right parties which were on the rise in Europe (Altınbaş,2007:119). Consequently, integration and liberation policies and partially multi-cultural characteristics of Europe were affected by the rise of ultra-right thoughts across Europe in 1980s. This situation has evolved in a unilateral practice which only obligated minorities to integrate into their resident country and dominant society (Barın,2014: 77). In line with this policy, precautions reinforcing integration have been taken while limiting immigration. These policies took effect for immigrants and Muslims.

The global financial crisis has been another recent political propaganda tool of the rising ultraright stream in Europe. The crisis triggered by bankruptcy of the giant American investment banking institution, the Lehman Brothers, in 2008, was felt all over the world and its devastating consequences were observed in the European continent, where Central and Eastern European countries needed saving packages of the IMF and debt crisis deepened especially in Greece and other southern European countries.(Elmas\&Kutlay,2011:15). As Europe was experiencing a downfall in public welfare due to the economic crisis, extreme-right parties developed a perception which viewed immigrants as not primary citizens of their countries, and adopted discourses blaming immigrants and especially Muslims as a burden on their national economy.

One of the extreme-right discourses which has been transformed into Islamophobia is related with Schengen crisis. Following Arab Spring Break Out which spread very quickly through North Africa and Middle East in February 2011 new debates about giving a new form to the regions in the post-spring era emerged, but some political groups in Europe degraded this issue down to a refugee crisis. European countries transformed the issue into the Schengen crisis by focusing on the refugee burden instead of approaching the issue through a comprehensive point of view. Crisis nurtures ultra-right inclinations through two different channels of refugee issues, one of the essential elements is the populist discourse, and the other one is emphasizing national priorities and values (Elmas\&Kutlay,2011:17).

Although it is wrong to approach all extreme-right parties in Europe like they are identical organizations, these have certain common characteristics. By their nature they are inclined to be authoritarian, radical, populist, nationalist and racist as well as having skeptical approaches towards globalization and European integration (Kakışım,2016:118-119). While they view the dominant ethnic and religious group as "us", the rest as "others", many of them are still regarding themselves as anti-Semitists. As they bear a phobia against "others", they are against pluralist democracy and multiculturalism. These parties believe they are privileged to take advantage of employment and public welfare in their country as dominant ethnic group, and owner of the country. Anti-immigrant stance is one of the identical characteristics of ultra-right parties (Ecevit, Ünal, Öner \& Özdemirkıran,2014:2). They view immigrants as causes of all problems by "alienating" them. These parties are not only influenced by targeting immigration in Western Europe, but also in Eastern Europe as well, such as Bulgaria and Romania. While Bulgarian ultra-right parties "alienate" Turkish minorities, the ones in Romania alienate Romanies. In Western Europe Anti-Islamism, in Eastern Europe Anti-Romany and Anti-Semitism are frequently exploited by extreme-right parties (Güler,2014:1). Following Table displays extreme-right parties and their fundamental political discourses. 
Table 1. Prominent Extreme-Right Political Parties and Their Basic Discourses

\begin{tabular}{|c|c|c|l|}
\hline Country & Political Party & Establishment & Discourse \\
\hline Austria & Austria Freedom Party & 1956 & Populism, European skepticism, anti-immigrant stance \\
\hline Belgium & Flaman Interests Party & 2004 & Flaman nationalism, separatism, anti-immigrant stance \\
\hline The UK & British National Party & 1982 & Populism, European skepticism, white nationalism \\
\hline Bulgaria & Ataka & 2005 & $\begin{array}{l}\text { Bulgarian nationalism, European skepticism, anti- } \\
\text { globalization, anti-Semitism }\end{array}$ \\
\hline Denmark & Dansk Folke Party & 1995 & Populism, social conservatism, European skepticism \\
\hline Finland & True Finns & 1995 & Nationalism, social conservatism, European skepticism \\
\hline France & Front National & 1972 & Protectionism, Populism, social conservatism \\
\hline Holland & Freedom Party & 2006 & Conversationalist liberalism, anti-Islam stance, Populism \\
\hline Sweden & Sweden Democrats & 1988 & Nationalism, European skepticism, Populism \\
\hline Switzerland & Switzerland Public Party & 1971 & National conservatism, Populism \\
\hline Italy & Northern League & 1991 & Regionalism, federalism, Populism \\
\hline Hungary & Jobbik & 2003 & $\begin{array}{l}\text { Nationalism, political radicalism, European skepticism, } \\
\text { anti-Semitism }\end{array}$ \\
\hline Norway & Progress Party & 1973 & Conservatism, Populism, Economic liberalism \\
\hline Greece & Golden Down & 1993 & Political radicalism, xenophobia stance, Neo-Nazism \\
\hline
\end{tabular}

Source: Al Jazeera, http://www.aljazeera.com/indepth/interactive/2013/02/2013224123927515709.html) (November $16^{\text {th }}, 2015$ )

According to the table above, political discourses of these parties are quite similar to each other. However, there are different core discourses in the outline of the social dynamics of each country. It would be useful and enlightening to track nationalist voting rates according to countries in exploring factors that lead to the rising of extreme parties. The following table summarizes the voting rates of these during parliamentary elections held throughout Europe during 2005-2013.

Table 2. Vote Rates of Extreme-right Parties for the Period of 2005-2013

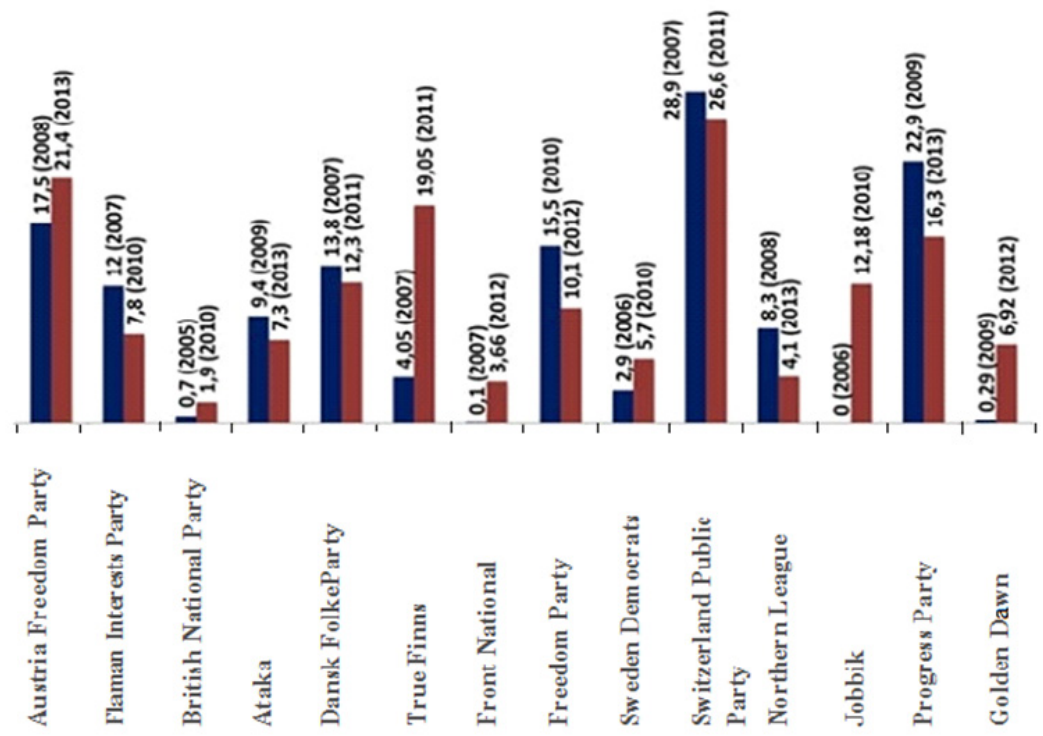

Source: Güler (2014:4) 
The most remarkable point in the graph showing the results of parliamentary elections is the higher rates of votes received by extreme-right parties in northern European countries such as Sweden and Finland. The Northern Europe indicated as the wealthiest region of the world, is also one of the places with high political tolerance culture. For this reason, it is surprising to observe the expansion of extreme right movements in Northern Europe. (Güler, 2014:1). In the 1990s, the common rhetoric of these parties was based on anti-immigration and anti-Islamism. In these countries the extreme-right parties often promise to reduce taxes and protect their national culture. On the one hand many European voters see the immigrants as a heavy burden on taxes paid to government and a significant threat to their national culture. On the other hand European people are losing their confidence in EU. Following on from the crisis in 2008, there are factors which are directing northern European voters towards these parties (https://euobserver.com/news/30797) (November $\left.16^{\text {th }}, 2015\right)$.

Another issue to be addressed in the table above is the significant increase in the vote proportion of extreme-right Austrian Freedom Party in the last elections in Austria, which is one of the least influenced countries by the economic crisis. The most fundamental reason for such a rise in the vote rate of this wing is considered as the necessary financial support expected from Austria for the member countries struggling with crisis. Austrian voters reflected their disapproval against financial support policy of the government during elections and this caused the Austria Freedom Party to increase its vote rate. This attitude of the Austrian public opinion could be seen as evidence showing that co-operative culture has not developed sufficiently in the EU. This situation also reveals that common "European identity" consciousness" has not matured among European societies and national identities still override their common identity.

Another extreme-right party rising notably is Jobbik (Jobbik Magyarországért Mozgalom Movement of better Hungary) in Hungary. Jobbik is especially radicalized with its policies developed against Romanians, who are the most populated ethnical minority of the country. Ultimate target voter group of Jobbik is the youth in elections. (http://www.democraticunion.eu/2013/11/popularityextremism-among-youth-europe-case-hungarys-jobbik-party/) (November $16^{\text {th }}, 2015$ ). Thus, on the basis of Jobbik movement, it is not wrong to conclude that the target age group of other extreme right parties is 18-22. This will be a great risk in the future in terms of socio-political integration in the EU. One of the essential objectives of the EU is to create a youth which accept the European identity rather than their national identity. Nevertheless, this new generation which put their national identities to forefront is considered as a significant threat to the supra-national structure aimed by the EU through preserving their nation-state status.

Golden Down (XpuøńAuүń), a Greek Political Party, is another prominent ultra-right party which increased its vote rate remarkably. Golden Down acquired an important success in the elections held in June 2012; its vote rate increased from $0.29 \%$ in 2009 to $6.92 \%$. As a result, the party gained 18 chairs in the Greek Parliament and became the fifth largest party in the country (Güler,2014;2). The economic crisis experienced in the country was seen as the most important factor contributing the rise of Golden Down. Yet, rising inflation and the decline in Greek society's purchasing power accompanied with high unemployment rate, which steered some groups to display a more conservative attitude towards immigrants and foreigners in the country. According to the recent polls in the country, vote rate of the Golden Down is estimated to be $11.5 \%$, which enables Golden Down to overcome PASOK (Panhellenic Socialist Movement), a deep-rooted party, and became the third party after SYRIZA (Radical Left Coalition) and New Democracy Party (http://www.ekathimerini.com/156456/article/ekathimerini/news/new-poll-gives-syriza-clear-leadover-new-democracy) (November $16^{\text {th }}, 2015$ )

Finally, both the extreme-right Parties and various right-wing politicians have increased their votes in general elections and followed propaganda methods that feed Islamophobia and antiimmigrant stance. In order to comprehend these approaches which increase Islamophobia, evaluation of various examples from prominent countries would be useful. 


\section{Islamophobic Discourses and Actions in Major European Countries}

\subsection{Austria}

In Austria, Islamophobia is frequently exploited by populist parties such as Austria Freedom Party (Freiheitliche Partei Österreichs-FPÖ) which was founded in 1956. It utilized the concept of Islamophobia in the parliament elections in 1999 for the first time. Their Islamophobia based election campaign was launched in 1999 and continued in their Vienna election campaigns in 2005. They added a new dimension to it by using the billboards full of mottos such as "Pummer's Bell instead of Muezzin", "Vienna First! Instead of Turkey in the EU" These posters were used by the ones who are against obligation of women wearing the burqa as well. Furthermore, it was emphasized that immigration of Muslims needs to be opposed because they are a threat to Europe (Canatan\&Hıdır,2007:355-363). Moreover, mosque attacks have intensified in Europe recently. For instance, in Vienna sections of pork were hanged on the door of Kocatepe Mosque maintained by the Turkish Islam Union. An agent from the Turkish Islam Union made a statement saying: "This attack was not only targeting Muslims, rather the target was the whole humanity. We will keep our coolheaded posture as Muslims". During 2014, similar incidents were repeated at various times. In the Aid-ul Fitr, five pork heads were placed at the construction site of the Eyüp Sultan Imam Hatip High School in Vienna. Additionally, a "Nazi" symbol was drawn on the wall of Eyüp Sultan Mosque in Telfs City of Tirol State (http://www.ntv.com.tr/dunya/Europeda-irkcilar-camileri-hedefaliyor,MPkBm3a3TkuJwoeTjuDg1A) (November $\left.23^{\text {rd }}, 2015\right)$.

\subsection{Germany}

Throughout Germany's history there have always been safe places to hide, for radical right-wing groups and racists. A painful example of this happened in Solingen City on May $29^{\text {th }}$, 1993 , causing the death of five Turks as a result of arson of their house. This aroused the interest of public opinion when it is understood that the murders have been committed by neo-Nazis. Furthermore, the investigation revealed murders of ten other foreigners by Neo-Nazis, which is publicly known as "murders of dönerci", once again suggested that Neo-Nazi reality should be perceived as a threat. The proportion of the 3.5 million Muslims in the overall German population is $3.9 \%$. Neo-Nazis and extreme-rightists use immigration as a rationale for their actions. Public statements that support this argument are very influential in terms of building public opinion. For example, Thilo Sarrazin, the leader of the Social Democrat Party, stated that "There are no other immigrant groups like Muslims who are heavily dependent on crime and social aids provided by the government" (Yanarışık, 2013: 2914). The majority of German society has an opinion that Germany is under the threat of an immigrant invasion; they believe that unemployment problem could be solved if immigrants are sent back to their countries.(Erdin, 2014:55).

In November 2011, Germany was shocked by another extreme right terrorist attack. Ten people were murdered during the 2000-2007 period by a Neo-Nazi terrorist group, and the victims were eight Turks, one Greek and one German. It is remarkable that the name of this terrorist group resembles the name of Hitler's National Socialist Party (Nazi) as this organization models Hitler's. According to the allegations about the German Intelligence Service in 2013, members of this organization adopted more racist and anti-Islamic attitudes and discourses; and even it was reported that one of the members has an object depicting "a crusader who aims his sword towards a mosque". Upon exposure of this scandal by the national media, some commentators pointed out that although German Intelligence was informed beforehand, it committed fraudulent concealment by avoiding taking any action to prevent these attacks targeting many Muslims (Erdin, 2014:56). The rhetoric and actions of opinion leaders in public are also harboring Islamophobia. For instance, Udo Ulfkotte, chair of the Pax Europe Association, did not hesitate to use a discourse to identify terrorism with Islam. Ulfkotte who once worked for a popular newspaper, FAZ (Frankfurter Allgemeine Zeitung), made statements regarding his objectives to found an anti-Islam party to prevent Islamization of Europe (Canatan\&Hıdır, 2007:324).

Recently, Pegida Movement which was founded in Germany and expanded across Europe 
has become one of the most prominent organizations using racism, xenophobia and Islamophobia. Pegida (Patriotische Europäergegendie Islamisierungdes Abendlandes -Patriot Europeans Against Islamicization of West) was founded on October $20^{\text {th }}, 2014$ as a new phenomenon in the world agenda. The Pegida was the result of the fight between two groups in Dresden following the attack of ISIS to Kobani City. The first public demonstration of Pegida started with a group of 300 people who were not happy with the fight in Dresden and wanted to bring the fight from the Middle East into Germany (http://www.lpb-bw.de/pegida.html) (November $\left.19^{\text {th }}, 2015\right)$. After this demonstration, Pegida has organized regular meetings every Monday. Audience of these meetings has grown larger thereafter. From October to January 2015, the number of attendees these demonstrations has reached to 25,000 . As a result of this growing interest, Pegida required the official bodies to gain a status of public association for common interest.

According to the Pegadian spokesman Lutz Bachmann, people were supporting Pegida because it was bravely bringing some issues to the agenda. (http://www.mdr.de/mdr-aktuell/pegidainterview-extremismusforscher100_cpage-7_zc-5f8e8344_zs-046016ee.html) (November $\left.19^{\text {th }}, 2015\right)$. Pegida was primarily bringing Is $\bar{a}$, the media and political parties into public attention (http://www.mdr.de/sachsen/pegida-proteste-dresden100_zc-f1f179a7_zs-9f2fcd56.html)

(November $19^{\text {th }}, 2015$ ).

Although it was claimed that Pegida was not initiated against Islam, it is an undeniable fact that it was grounded upon the Islamophobic hate rooted in the fear of Islamicization of Western world. The movement is led by extreme-rightists supported by Neo-Nazis and radical right wings. One the one hand Pegida declares that they are opposed to a religion war in Germany. On the other, they emphasize the importance of preservation of German culture and maintaining values. (http://www.diken.com.tr/9-soruda-pegida-son-German-fenomeni-hakkinda-bilmeniz-gereken-sey/) (November $\left.19^{\text {th }}, 2015\right)$.

Moreover, they harshly criticize the attitudes of political parties as an opposition party. Regarding the approval of the immigration of 20,000 Syrians due to the recent civil war in the country, Pegida members expressed their discomfort with the situation and they insisted that the economic aid allocated to Syrian migrants needs to be spent on economically disadvantaged Germans in their home country (Alkan,2015:284).

Another issue stressed by the Pegida is media. Pegida calls German media as "lügenpresse", In other words, they accuse them of being liars. According to Pegida supporters, they are intentionally labeled as extreme-rightists, racists or anti-Islamists by German media (http://www.spiegel.de/kultur/gesellschaft/pegida-kampfbegriffe-was-verbirgt-sich-hinter-der-

rhetorik-a-1011755.html) (November $\left.19^{\text {th }}, 2015\right)$. For this reason, the Pegida is determined not to give press releases to the media on the grounds that they are "liars".

Based on the results of a survey conducted by the University of Dresden on Pegida supporters in January 2015, the general demographic characteristics of them were as follows (http://tu-dresden.de/aktuelles/news/Downloads/praespeg) (November $19^{\text {th }}, 2015$ )

They are:

* In middle economic class,

* Highly educated,

* From Dresden or Saxony provinces, receiving good salaries in good positions,

* Middle aged and male,

* Not members of any political party,

* Mostly atheist.

Seventy percent of protesters are employed rather than being retired or unemployed. Only $25 \%$ of true supporters of Pegida stated that they view Islam as a threat or something to be afraid of. Additionally, $20 \%$ of this group stated that they support Pegida because they are not satisfied with the refugee policy in Germany. Frank Richter classifies supporters of Pegida movement in four groups (Alkan, 2015:285):

* Hooligans and sympathizers of NPD (Extreme-right Germany National Democratic Party),

* People worrying about future of German culture and traditions,

* Individuals criticizing the refugee policy of the current government,

* Disconnected and disadvantageous individuals in society. 
According to the manifest comprised of 19 articles published by Pegida movement on December 2014 to express policies of the organization, subjects defended by Pegida were given as below:

* Criminal immigrants and refugees need to be deported without any delay

* Refugees should not be concentrated in a center; they need to be distributed to all states in Germany.

* EU needs to establish a central body for refugee affairs which maintains their record and distribute them to member countries.

* A Larger budget needs to be allocated to security departments.

* The controlled force model like in Canada, Switzerland and South Africa needs to be administered.

* Refugee applications need to be settled in a short time; deportation and adaptation processes must be run more efficiently (Alkan,2015:286).

Together with some expressions need to be removed from the manifest, Pegida's discourse could be given as follows: Pegida thinks that Germany is being Islamized. However, the rate of the Muslim population in the Saxony state which displays the highest participation into Pegida is only $0.1 \%$. Overall Muslim population was 4.5 million in 2010 . The slogan "We're the people" is shouted by Pegida during Monday demonstrations and it is the discourse related to the spirit of collaboration adopted by East Germans during demolition of the Berlin Wall in 1989. Pegida aims to create a historical phenomenon by using this discourse. Pegida is disturbed by immigrants and refugees because they believe that they use the resources of the German people. It is emphasized that the allowance of $€ 362$ for every refugee in Saxony costs every German citizen $€ 1630$ per year and that this amount needs to be used for the welfare of German citizens (http://www.diken.com.tr/9soruda-pegida-son-German-fenomeni-hakkinda-bilmeniz-gereken-sey/) (November $16^{\text {th }}, 2015$ ).

Although Pegida has started as an Eastern Germany phenomenon, it has got a foothold shortly in the UK, Austria, Denmark, Norway, Czech Republic and Sweden. They believe that certain precautions need to be taken against Islamophobia which has further intensified in the aftermath of September 11 attacks. Yet, anti-Islamic movements across Europe have evolved into street demonstrations in some countries. If member countries of the $\mathrm{EU}$ attach value to different cultures as they underlined in their discourse, they should not allow the formation of movements like Pegida; and try to combat anti-Islamic alliances, xenophobia and racism. They should also avoid populist and short-term policies on the continent.

\subsection{France}

France which is the home of more than five million Muslims has banned the use of veil in the public arena in 2011. In 2012 in Poitiers City, a fascist group calling themselves "732 Generation Identitaire" occupied the construction site of a mosque. The group consisted of sixty young people, naming themselves as a reference to the year $732 \mathrm{AD}$, when the Muslim armies were defeated by the French and stopped in European history. Jean Marie Le Pen, the leader of extreme-rightist Front National Party, states that all foreigners, especially the Turks, should leave the country. Le Pen, in one of her public statement, remarked that Muslims praying in mosques resemble Nazis. According to the report published by the Association for Collaboration Against Islamophobic Assaults in France, "Collectif Contre I'Islamophobie en France" (CCIF), only verbal violence against Muslims increased by $134 \%$ in 2011 . Three hundred sixty-four Muslims were exposed to physical or verbal violence either on private premises or public places in 2012. Similarly, while 298 physical attacks were recorded against Muslims in 2011, this figure increased to 414 in 2012. Additionally, racist violence against Muslims at workplaces increased by $7 \%$. According to this report $87 \%$ of the victims were women, mostly attacked because they wear a headscarf. The report also claims that every week a mosque becomes the target of these attacks. In other words, 50 mosques were attacked only in 2012 in France (Erdin,2014:37-38).

Debates on Islamophobia peaked with the publication of a cartoon humiliating Muslim Prophet Mohammad in a comic magazine called Charlie Hebdo. Muslim populations around the world reacted to this so-called "joke". Gerard Blard, the Executive Editor of Charlie Hebdo, stated that "we 
view this publication as a part of our work and free thought". French Government perceived the incident as a "freedom of thought" (Erdin,2014:39-40).

Finally, in a cartoon with the title "Immigrant" published by Charlie Hebdo in January $13^{\text {th }}$, 2016, (http://www.bbc.com/turkce/haberler/2016/01/160113_charlie_hebdo_aylan_kurdi) (January $15^{\text {th }}, 2016$ ), there is a question placed beside the illustration of the dead body of Syrian Aylan Kurdi who was drowned with his mother and sister at the age of three while his family was illegally trying to reach Greece's Kos Island on February $2^{\text {nd }}, 2015$ in an inflated boat. The question is "What would little Aylan be when he grows up?" There is an expression of "Tripoteur" meaning "harasser" which is used in French to refer the ones harassing others behind them. Right under the question there is a woman running away from two men who are chasing her. Both their hands are open to imply that they would sexually harass the people, if they could reach Germany.

\subsection{Norway}

Norway is known for its welfare and tolerant environment instead of violence and terror. Nevertheless, an incident occurred in 2011 shocking not only Norwegians, but the world deeply. Anders Behring Breivik first committed bomb attacks in Oslo then an armed assault on a youth center located in Utoya Island in the neighborhood of Oslo on July $22^{\text {nd }}, 2011$. Breivik killed seventyseven innocent people and wounded two hundred forty others. Breivik stated that he was against multiculturalism and foreigners, and that Islam is a dangerous religion. Before committing these attacks, he published 1516-paged manifest with the title of "A European Independence Declaration" in which he claimed that the salvation of Europe depends on returning to core values of Europe and that other different cultures which cause impairment of the European races need to be wiped out. As Breivik exposed his anti-Islam view with his expressions such as "We do not want Islam and Muslims", "Islam religion is an open enemy of progress of world" (International Terrorism and Security Research Center, UTGAM, 2012:3), he declared that he did not want the Norwegian Court supporting multiculturalism. Breivik used the Nazi salute and, acknowledged this but refused to admit that he was guilty (Erdin,2014:42). This unfortunate incident was required to be analyzed in the context of Islamophobia reaching across Europe. Hence, it is a case which exhibits dangerous consequences of radicalism that may arise among people because of false information and misunderstandings.

\section{Policies for Fighting Against Islamophobic Discourse}

While multiculturalism is an indispensable reality of integration process in Europe, it means diversity of European societies. On the other hand it might be an obstacle before integration. The progress achieved within this comprehensive policy is also open to social marginalization. In this sense, developing extensive policies for Islamophobia and xenophobia was triggered by many sociocultural, political and economic factors, so, it is important for Europe to relate the values of its integration project with fundamental rights and freedom (Elmas,2008:127).

While dealing with the contemporary social and economic problems, the fight against Islamophobia is one of the issues which is evidently dealt with almost unbelievable incompetence by the human rights activists. Indeed, if the numbers of acts, international summits and action plans in the last two or three decades, are taken into consideration, it would not be considered a misjudgment to say that one of the main ideas promoted by the human rights law is to fight against xenophobia and Islamophobia.

Legal acts and agreements are carried out within the framework of international cooperation, which forms the basis of the fight against the increasing Islamophobic wave in Europe. Public initiatives, demonstrations and action plans, the reports of various associations and research centers based on legal regulations aim to increase public awareness about the topic on the continent. 


\subsection{Studies Conducted within the Council of Europe}

In the summer of 2010, the general board meeting of the Council of Europe Parliamentary Assembly, discussed a report with the title "Islam, Islamism and Islamophobia in Europe" and the board criticized racist parties for inciting anti-Islamism across Europe. It was emphasized that extreme-right parties had recently been targeting Muslims to develop their own policies. It was made clear that "xenophobia was replaced with fear of Islam". While many Muslim immigrants in Europe are reported to adopt European cultures and values, anti-Islamic practices and racist parties have recently increased the reaction of Muslim youth against these western values. In the result section of the aforesaid report, it was emphasized that "cultural and social discrimination against Muslims must be eliminated in Europe" and "European Council is required to discuss common strategies which can be used to fight against anti-Islamism". Whereas the member countries of CE addressed the importance of religious education including various faiths, it was requested from higher education institutions to support Islamic researches in Europe. Moreover, the importance of a better expression of Islam in schools was mentioned (Erdin,2014:53).

In 2011, a report "Living Together: Bringing Diversities and Freedoms Together in the $21^{\text {st }}$ Century's Europe" was published by the CE Elites Group. An opinion survey conducted by the Pew Global Attitudes Project confirmed the increasing trend in negative attitudes towards Muslims in Europe. In some European countries, the percentage of respondents whose consideration about Muslims was "some negative" or "very negative" increased remarkably in the period of 2004-2010. Other studies conducted in Europe confirm that negative views about Muslim minorities were rather common. Even the report drawn attention to population growth of the Muslim minority and the fact that Islam is perceived as a primary threat by many Europeans who think that Islam could not conform to "modern European life"(Report of CE Elites Group,2011:14).

Furthermore, according to the 2014 Report issued by the European Commission against Racism and Intolerance (ECRI), the crises which occurred in the Middle East in 2013 elevated racism, Islamophobia, anti-Semitism and xenophobia in Europe. The report underlined that antiSemitist discourses progressively increased in some countries where there are Muslim immigrants and also that anti-Semitism increased among youngsters. Moreover, the report said that Islamophobia has become a rising trend across Europe. Political leaders have used this status as a political tool by associating terrorist incidents with Islam and Muslims. The report also highlighted the fact that the ideology claiming Islam conflicts with the European values has been imposed which sets the ground for anti-Islamist ideologies. It was reported that Afro-Europeans are more frequently checked by police in comparison with white citizens and they are in a more disadvantageous position in terms of using social services. The secretarty of CE, Thorbjorn Jagland, called for political leaders to adjust tones of their discourses by stating that "The most important threats to the future of Europe are Islamophobia, Racism and Anti-Semitism" (http://www.hurriyet.com.tr/Europeda-irkcilik-ve-Islamophobia-artti-29507081). (November 23 ${ }^{\text {rd }}$, 2015).

\subsection{Actions of the European Union in Fighting against Racism and Islamophobia}

The Charter of Fundamental Rights could be considered as the beginning of actions of the EU against racism and Islamophobia. This charter gained status of joint declaration of three bodies after it was executed by the chairman of the Council and Commission on April $5^{\text {th }}, 1977$ (Tezcan,2002:152). Although this declaration was not containing an exclusive title concerning racism or Islamophobia, it is important since it addresses the EU's devotion to preservation of fundamental rights. Following the Charter, on May $29^{\text {th }}, 1990$, it was issued "The Resolution for Fighting against Racism and Xenophobia" which emphasized the importance of an effective and preventive education policy, the role of media, potential contributions of exchange programs and especially fighting problems related to the education of immigrant children; and member countries were invited to take further and relevant steps (Elmas,2008:128). Besides, on the ground of council regulation with 1035/97 enacted on June $2^{\text {nd }}, 1997$, the European Monitoring Centre on Racism and Xenophobia (EUMC) was founded. The center's primary goal is to help to provide racism- 
related, objective, reliable and comparable data about xenophobia and Islamophobia to the EU and its member countries when they take measures or action within their jurisdiction. Other goals of the center include investigating the development and dimensions of racism, xenophobia and Islamophobia as well as analyzing associate causes, results and impacts of them (Elmas,2008:153154).

According to the report "Muslims in the EU: Discrimination and Islamophobia" (2006:1) published by the EUMC;

* Substantial portion of Muslims experience discrimination regardless of their ethnic identities and/or religious approaches in terms of employment, education and accommodation.

* Discrimination against Muslims could be associated with the Islamophobic attitudes as well as grudge interrelated with racism and xenophobia.

* Although data concerning religious-driven incidents are limited, it is known that Muslims incur various Islamophobic assaults ranging from verbal to physical attacks.

* The data in the report suggest that while academic success of European Muslims is below the average, their unemployment rate is above it.

* Muslims are usually employed in positions requiring low professionalism for low wages.

* Numbers of European Muslims, especially Muslim youth, face obstacles before their social development. This situation would cause desperation and social exclusion feelings.

* Racism, discrimination and social marginalization constitute serious threats to integration and social integration.

Another organization founded within the European Union, which focuses on studies on Islamophobia is the European Union Fundamental Rights Agency (FRA). The FRA was founded in February $15^{\text {th }}, 2007$ by expanding task description of the EUMC. The objective of the agency is to provide assistance and consultancy to the relevant institutions and organization of EU and member countries when they take measures or determine attitudes within the boundaries of their expertise to ensure full conformity with fundamental rights (Elmas, 2008:186-187). The report which focuses on the discrimination against Muslims was prepared by the FRA, and it was a part of the first study conducted across the continent about the experiences of immigrants and ethnic minorities regarding discrimination and racist violence. In this study, data collected from Muslim respondents indicate, higher discrimination and suffering rates than other minority groups. On average, 1 out of every 3 respondents experienced discrimination in the last 12 months; $11 \%$ of subjects incurred a racist violence.(The Report of the European Union Fundamental Rights Agency (FRA), 2009:1-4).

\subsection{Activities of the Organization for Security and Co-Operation in Europe}

OSCE describes hate crimes as "prejudice crime" in the guidebook prepared for prevention of hate crimes. The most evident factor distinguishing these crimes from others is prejudice because criminal selects inherent characteristic -such as ethnicity, race, language, religion, nation etc.- of the victim as a target on purpose. ECRI made suggestions that discrimination, hate and violence based on race, religion, language, skin color, nationality or ethnic origin could be considered as racist discourses and required to be recognized as crime by the regulations (Erdin, 2014:79). It is possible to include Islamophobia within the scope of the hate crimes. In this sense, exposure to discrimination or incurring violence because of Muslim identity, being threatened for violent actions mean that racism which was present in the pre-WWII period across Europe appears once again in another form in the post-cold war period. Thus, since there is a potential that discourses elevating Islamophobia would evolve into violence targeting Muslim societies threaten the peace and security in Europe, international and supra-national organizations having European origins are required to fight against this issue effectively.

\subsection{The United Nations (UN)}

As European countries are members of the UN in the meantime, it is worth mentioning the efforts and the relevant decrees taken by the UN. According to the agreement executed by the UN 
General Assembly, which took effect on the 1st April, 1969, the UN request signatory countries of the relevant agreement to obey the "International Convention on the Elimination of All Forms of Racial Discrimination". As of today, while there are 178 signatory countries of the aforesaid agreement, 88 countries approved and put this act in action. This agreement forbids all sorts of racial, ethnical, national discrimination, exclusion and privilege (http://www.ohchr.org/EN /Professionallnterest/Pages/CERD.aspx) (October, 22nd, 2015). On the other hand, it could be seen that the study provides various examples of Islamophobia-based discrimination and alienation from Germany, Austria, Denmark, Holland, Norway and Hungary, which are signatory countries of this treaty. (https://treaties.un.org/Pages/ViewDetails.aspx?src=IND\&mtdsg_no=IV-2\&chapter=4 \&clang=_en) (October, 22nd, 2015).

Moreover, it is emphasized that the United Nations agreement respects the principles of dignity and parity of all humankind and that all member countries are expected to respect human rights and fundamental freedom of all people regardless of their race, gender, language or religion within the scope of purposes of the UN (Gemalmaz,2010:345-346). In the meantime, the universal declaration of human rights underlines that each and every human being is born with natural freedom and they are equal to each other in terms of human dignity and rights, and that all human beings are entitled to rights and freedoms without any discrimination on the ground of their skin color or background such as their nationality and ethnicity (UN,1969:1). Additionally, "The International Covenant on Civil and Political Rights" was enacted by the General Assembly of the United Nations on the $16^{\text {th }}$ December, 1966 and took effect on the $23^{\text {rd }}$ March, 1976 . This covenant states that all signatory countries will protect and respect all individuals who live in their territory and subject to their sovereignty without discriminating them because of their race, skin color, gender, language, religion, national or social origin, prosperity and birth (UN,1976:54).

\section{Dilemmas Encountered During Fight Against Islamophobia}

Fighting against Islamophobia, requires taking social, political and legal policies to be taken into consideration from a multi-dimensional perspective. Yet, as it was mentioned in the prior sections, Islamophobia has evolved in different forms, so it is subject to religious, social, political and economic transformations over the time by trespassing theoretical explanations.

In the light of reality indicated above, the most criticized dimension of the policies and initiatives across the European continent is the existence of a discrete and distributed policy network. In general, since legal measures taken under the roof of the EU have limited the impact on their own, suggestions introduced by different institutions and reports are formed in this line. Legal regulations, support from political leaders, education, analyses, and research studies are required to be supported by raising awareness of civil society (Elmas, 2008:193-194). Furthermore, besides following pro-active policies and maintaining a multi-dimensional fight, the need for institutional expansion voicing a single word are the domains expected to gain further progress by the EU. Since decisions of whether to support a policy or decision regarding the war against Islamophobia in Europe is left to the discretion of current administrations of member countries, which influences immediate public opinions in parallel with daily political atmosphere, and might cause various legal gaps, which could deteriorate the essence of this initiative. These gaps created along the way of fighting and downshift effectiveness of policies set against Islamophobia across the EU, and when this situation accompanies with disagreement within individual member countries and within the EU as a whole, common ground could not be created for a persistent resolution. Yet, policies that will be structured by means of the EU's social, political and legal tools as well as legal regulations would make the fighting against Islamophobia more tenable and legitimate at certain level in the eye of public opinion.

When debates concerning whether Europe is following an effective fighting strategy based on its ancient experiences are approached from the point of individual countries, it is seen that the policies accepted by member states are different from one another. Although some of the member countries have taken positive steps in fight against Islamophobia, some still and pave the way of social disintegration and prejudice by avoiding taking the necessary steps to motive society in a positive way. Associating socio-economic depressions and violent incidents with "alienating Islam" 
and blaming Muslims are definite reflections of this approach. Ongoing debates on immigrant laws and the firm control of borders represent an established Islamophobic tendency across Europe. At this point, all members of the European community need to put their individual identities aside and public prejudices need to be broken down. When personal prejudices are transformed into discriminations, it is moved away from living together with different cultures and it shows up a ghetto culture. Muslims who build their own world demand recognition of their religious holidays as well as more respect to Islam in social domains. The cultural life which has emerged in the Western world on its own is referred to as "Euro Islam" by some scholars. This understanding which could be referred as "European Islam" came to existence in order to bring Muslim culture, Islam together with European socio-economic values by the Muslims living in European continent (Erdin,2014:7576). Individuals are able to maintain their lives within a multi-cultural setting by acknowledging their differences.

Accordingly, Islamophobic approaches push foreigners towards ghettos and isolated neighborhoods outside regular living neighborhoods. Thus, native Europeans' living areas are "cleared" off from such subjects, who draw solid outline of Islamophobia by means of cultural and religious codes. This creates an artificial border dividing dominant strain, religion, culture and civilization from the others and does not permit outsiders to enter (Sumbas,2009:276-277). Such an approach evolves into a structure that feeds the conflict among societies who regard each other as enemies.

\section{Conclusion}

While bombing attacks all over Europe intensify global violence inclination, all Muslims are charged with terror actions that are alleged to be committed in the name of Islam. By taking advantage of this status quo European extreme-right parties taking initiative to manage public perception by demonstrating Islam as religion of violence and Muslim as 'terrorists.' Increasing popularization of extreme-right parties in elections both within national borders and in elections of the European Parliament could be interpreted as a deliberate indicator of this situation. European extreme-rightist politicians have replaced communism threat with xenophobia -especially against Muslims- in the post-cold war period as a new propaganda tool, and they caused the expansion of Islamophobia across the continent by blaming Muslims to be the causes of internal problems faced in different European countries. All these circumstances are strengthening extreme-right movements to threats to the principles and values of democracy, human rights and plurality upon which the EU project was erected. The European leaders who provided the integration in Europe by emphasizing that it is possible to live together in a multi-cultural environment now come to an agenda of the public opinion with their statements voicing that multi-cultured live is an illusion.

Perceptions towards workers -majority of whom are Muslims- who were brought to Europe in 1960s for supplying workers for labor deficit have evolved to be regarded as a burden in parallel to the economic crisis which broke out in Europe. Thus, an immigrant crisis has become a major issue in Europe. These workers have started to be seen as an excessive load as they have been experiencing difficulties while integrating to the European culture even though they have contributed significantly to the socio-economic development. Furthermore, the refugee crisis caused by the violent incidents in the Middle East and the North Africa resulted in reconsideration of the Schengen Agreement which abolishes sovereign borders across Europe.

Furthermore, "unity in plurality", which is the official principle of the EU, needs to be reapplied; and it should be recognized that the EU was built on different cultures, languages and traditions and this cultural diversity is the integrating factor of the EU. Hence, necessary actions should be taken so that immigrants and ethnic-religious minorities contributing into the multi-cultured structure of the continent could adequately be harmonized with their resident countries. The perception that the EU has isolated itself against immigration must be changed; protection of minorities, a Copenhagen Criterion, must be put in action; status of minorities in member countries must be monitored and investigated regularly by the relevant EU institutions. At this point, the most important target group is the youth. Current prejudice of the European youth against immigrants and ethnic-religious minorities in their home country is required to be changed. Besides, the 
identification of European youth as European individuals instead of their national sub-identities is essentially critical for building up a collaboration culture within the EU. As long as a collaboration culture and multiculturalism are established across the union, the EU would become enduring against crisis that may happen in the future; and European society would not be in quest of radical paths (Güler, 2014: 4).

On the other hand, Islamic countries are also expected to take some measures against raising Islamophobia. Actions of terrorist organizations that claim to act in the name of Islam but in fact they do substantial harm to Islam and Muslims, causing prejudice in the society, are required to be prevented in Islamic countries. Hence, Muslim countries have the fundamental responsibility in this respect because terrorist organizations play a significant role in the proliferation of Islamophobia. Furthermore, Islamic countries need to undertake further responsibility in introducing Islam accurately to the Western world and to resolve Islamophobia issue in there. At this point, Turkey has a vital role such as Turkey's full and equal partnership to the EU after spending efforts for long years represents a significant and concrete step in the name of fighting against Islamophobia. Yet, as a country wich is primarily composed of Muslim population, Turkey's continuous efforts to accommodate common European values such as democracy, the rule of law and human rights and its governance under secular state principle would result in better comprehension of Islam by Europeans.

\section{Acknowledgement}

Hereby study was financially supported by the Scientific Research Project Coordination Department of the Karabük University under KBÜBAP-17-YD-283 project reference number.

This study is derived from the master thesis of Mehmet Akça, called "Changing Face of Racism in Europe: Islamophobia" was written under my supervision and the presentation was submitted in "Los Angles International Business and Social Science Research Conference 2017" held in Los Angles, USA on 7 - 9 July 2017.

\section{References}

Alkan, N. M. (2015). Avrupa'da Yükselen Irkçılık: Pegida Örneği. Gazi Akademik Bakış Dergisi, 8 (16), 275-289.

Altınbaş, D. (2007). Avrupa'da İslam Etkisi: Fransa Örneği. Doktora Tezi, Gazi Üniversitesi, Sosyal Bilimler Enstitüsü.

AlSayyad, N. \& Castells, M. (2004). Müslüman Avrupa ya da Avro-İslam. Çev.: Z. Savan, İstanbul: Everest Yayınları.

Aydın, M. Z. \& Yardım, M. (2007). Belçika'da İslamofobi ve Müslümanlara Yönelik Ayrımcılık. Cumhuriyet Üniversitesi İlâhiyat Fakültesi Dergisi, 12(2), 7-32.

Barın, H. (2014). İslamofobi: Bir Irkçılık Çeşidi ve Nefret Suçu. Yüksek Lisans Tezi, Gazi Üniversitesi, Sosyal Bilimler Enstitüsü.

Canatan, K. \& Hıdır Ö. (2007). İslamofobi ve Antiislamizm: Kavramsal ve Tarihsel Yaklaşım. Ankara: Eskiyeni Yayınları.

Ecevit, A.Y. \& Ünal, Ö. et. al. (2014). Avrupa Parlamentosu Seçimleri ve Aşırı Sağ Partilerin Yükselişi. Betam Araştırma Notu, 14 (167), 1-9.

Elmas, F. (2008). Avrupa Birliği'nde Irkçılık ve Yabancı Düşmanlığı ile Mücadele. Yüksek Lisans Tezi, Ankara Üniversitesi, Sosyal Bilimler Enstitüsü.

Elmas Yılmaz, F. ve Kutlay, M. (2011). Avrupa'yı Bekleyen Tehlike: Aşırı Sağın Yükselişi. USAK Analiz No: 11.

Erdin, M. (2014). 11 Eylül Saldırılar ve İslamofobi: ABD ve Avrupa'da Görülen İslam Karşıtı Eylem ve Hareketlerin Nedenleri ve Sonuçları. Yüksek Lisans Tezi, İstanbul Üniversitesi, Sosyal Bilimler Enstitüsü.

EUMC (2006). Avrupa Birliği'nde Müslümanlar: Ayrımcılık ve İslamofobi. EUMC Yayınları, 1-5.

Gemalmaz, M. S. (2010). Her Biçimiyle Irksal Ayrımcılığın Ortadan Kaldırılması Uluslararası Sözleşmesi. Ulusalüstü insan Hakları Hukuku Belgeleri, 2. Cilt, Uluslararası Sistemler, İstanbul, 345-367.

Güler, S. (2014). Avrupa'da Aşırı Sağın Yükselişi: Yunanistan'da Altın Şafak Partisi Örneği. Bilge Adamlar Stratejik Araştırma Merkezi Yayınları, Ankara, 1-9.

Kakışım, C. (2016). Sınıf, Etnisite ve Kimlik Sosyalist Paradigmanın Evrimi. İstanbul: İletişim Yayınları.

Sumbas, A. (2009). Batı Avrupa'da Yükselen Yeni-Irkçılık Üzerine Bir Deneme. Alternatif Politika Dergisi, 1 (2), 260-281.

Tezcan E. (2002). Avrupa Birliği Hukuku'nda Birey. İstanbul: İletişim Yayınları. 
The Report of the European Union Fundamental Rights Agency (FRA), 2009: 1-4

Yanarışık, O. (2013). Yükselen Irkçılık ve İslamofobi Gölgesinde Yaşayan Avrupa Türkleri: Almanya Örneği. Yeni Türkiye Dergisi, No: 54, 2911-2917.

https://euobserver.com/news/30797_(14 November 2015).

http://www.democraticunion.eu/2013/11/popularity-extremism-among-youth-europe-case-hungarys-jobbik-party/ (14 November 2015).

http://www.ekathimerini.com/156456/article/ekathimerini/news/new-poll-gives-syriza-clear-lead-over-newdemocracy (14 November 2015).

http://www.ntv.com.tr/dunya/Europedairkcilarcamilerihedefaliyor,MPkBm3a3TkuJwoeTjuDg1A (23 November 2015).

http://www.lpb-bw.de/pegida.html (14 November 2015).

http://www.mdr.de/mdr-aktuell/pegida-interview-extremismusforscher100_cpage-7_zc-5f8e8344_zs046016ee.html (14 November 2015).

http://www.mdr.de/sachsen/pegida-proteste-dresden100_zc-f1f179a7_zs-9f2fcd56.html (14 November 2015).

http://www.diken.com.tr/9-soruda-pegida-son-German-fenomeni-hakkinda-bilmeniz-gereken-sey/ (14 November 2015).

http://www.spiegel.de/kultur/gesellschaft/pegida-kampfbegriffe-was-verbirgt-sich-hinter-der-rhetorik-a1011755.html (14 November 2015).

http://tu-dresden.de/aktuelles/news/Downloads/praespeg (14 November 2015).

http://www.diken.com.tr/9-soruda-pegida-son-German-fenomeni-hakkinda-bilmeniz-gereken-sey/ (14 November 2015).

http://www.hurriyet.com.tr/Europeda-irkcilik-ve-Islamophobia-artti-29507081 (14 November 2015).

http://www.ohchr.org/EN/Professionallnterest/Pages/CERD.aspx (14 November 2015).

https://treaties.un.org/Pages/ViewDetails.aspx?src=IND\&mtdsg_no=IV-2\&chapter=4\&clang=_en (14 November 2015).

http://www.bbc.com/turkce/haberler/2016/01/160113_charlie_hebdo_aylan_kurdi(15 January 2016).

http://www.aljazeera.com/indepth/interactive/2013/02/2013224123927515709.html (November $\left.16^{\text {th }}, 2015\right)$ 